\title{
Visionary Leadership and Organizational Commitment: The Mediating Effect of Leader Member Exchange (LMX)
}

\author{
DHAMMIKA K. A. S. \\ Department of Human Resource Management \\ University of Kelaniya \\ SRI LANKA \\ kasdhammika@yahoo.com
}

\begin{abstract}
:-
Visionary leadership is one of the leadership aspects which have drawn much attention of researchers over the past years. As a result of this, it has been found that visionary leadership is positively associated with both organizational and employees outcomes. However, most of studies on visionary leadership has presumed a direct casual effect on these outcomes and has relatively neglected the indirect effect of visionary leadership by intervening with other organizational variables. The objective of the present study is to assess the effect of visionary leadership on organizational commitment (OC) with mediating effect of Leader Member Exchange (LMX).100 respondents were selected as the sample of the study using random sampling method. Standard questionnaires measuring visionary leadership, OC and LMX were administered for data collection. Hypotheses were formulated based on the literature review and tested with Structural Equation Modeling (SEM). It was found that there is a positive and significant relationship between visionary leadership and OC. Further, it was revealed that there is a significant indirect effect of LMX on the relationship between visionary leadership and OC. The direct impact of visionary leadership explains the much of variance of OC than the indirect effect through LMX. The implications of findings were discussed and further studies were proposed.
\end{abstract}

Key Words: -Visionary leadership, LMX, and OC

\section{Visionary Leadership}

Visionary leaders can be found in every facet of society, whether business, government, social change movements, religious organizations, community groups or sports teams (Kirkpatrick, 2004). Visionary leadership stands apart from other leadership behavior on the fact that they create an inspiring vision and communicate that vision among subordiantes so that organizations moves from good to better. Further, visionary leadership refers to the capacity to create and communicate a view of a desired state of affairs that clarifies the current situation and induces commitment to an even better future. Colton (1985) defines visionary leadership as one that "established goals and objectives for individual and group action, which define not what we are but rather what we seek to be or do" (p. 33).

Visionary leadership is said to have positive effects on follower outcomes, resulting in high trust in the leader, high commitment to the leader, high levels of performance among followers, and high overall organizational performance (DuBrin, 1998). This range of positive outcomes are brought by the balance concern on both the organization and subordinates. Visionary leaders are said 
to have insight into followers' needs or values and to develop a vision statement reflecting those needs or values (Kirkpatrick, 2004).

Researchers claim that this happens because the vision has positive effects on followers' selfconcepts; followers become motivated to achieve the vision because they find it meaningful, identify with it, and believe in the vision and their ability to achieve it. Effective communication of visionary leadership changes subordinates attitudes and outputs resulting in organizational trasformations (Waldman, Ramirez, House, \& Puranam, 2001). This way of behavior of visionary leaders will lead to better relationship with their subordinates and improving the OC of them. Shamir, House, \& Arthur, (1993) posited that visionary leadership minds on collective workout and collective commitment of the team. At the same time, they make the followers self sacrify and interlectually stimulating subordiantes with individualized consideration (Valenzuela, 2007).

Kirkpatrick, (2004) have presented a deliberate list of attributes of visionay leadersip that promote quality relationship and $\mathrm{OC}$ of subordinates. The following table depicts the major behavioral attributes of visionary leadership.

\section{Table I. Major Behavioral Attributes of Visionay Leadership}

\begin{tabular}{|l|l|}
\hline Empowerment. & $\begin{array}{l}\text { The leader's optimism and confidence in followers' abilities empowers } \\
\text { them to work toward the vision. Visionary leaders are confident that } \\
\text { followers will work toward the common vision rather than their own } \\
\text { personal agendas. The leader's high expectations have been found to } \\
\text { elicit high performance from followers. }\end{array}$ \\
\hline Image building & $\begin{array}{l}\text { Visionary leaders consciously build a positive image of themselves for } \\
\text { followers. Visionary leaders reflect the vision in their work lives, } \\
\text { personal lives, attire, and demeanor. Also, they often rehearse their } \\
\text { speeches in order to present the desired image in a dramatic fashion. }\end{array}$ \\
\hline Supporting & $\begin{array}{l}\text { Visionary leaders engage in unconventional behavior and may make } \\
\text { what the followers perceive to be sacrifices. (From the leader's } \\
\text { perspective, a sacrifice may not exist; instead, the leader may be entirely } \\
\text { focused on pursuing the vision.) These are not blind risks, however; } \\
\text { they are calculated. Visionary leaders carefully evaluate options. Risk- } \\
\text { taking behavior serves to promote change and innovation and to } \\
\text { challenge existing assumptions. }\end{array}$ \\
$\begin{array}{l}\text { Effective leaders support followers by providing them with } \\
\text { individualized consideration. Leaders provide emotional support during } \\
\text { difficult times or when followers become frustrated. Support can be } \\
\text { provided to groups of followers as well as to specific followers on an } \\
\text { individual basis. Further, leaders coach and mentor followers to } \\
\text { facilitate their development. }\end{array}$ \\
\hline
\end{tabular}




\begin{tabular}{|l|l|}
\hline \multirow{3}{*}{ Adapting } & $\begin{array}{l}\text { Responsiveness to a changing environment is another visionary } \\
\text { leadership behavior. Visionary leaders display flexible or versatile } \\
\text { problem-solving styles. They are effective at gathering, processing, and } \\
\text { distributing information to their organizations so that appropriate } \\
\text { responses can be carried out. }\end{array}$ \\
\hline $\begin{array}{l}\text { Intellectually } \\
\text { stimulating }\end{array}$ & $\begin{array}{l}\text { Visionary leaders are said to stimulate followers to challenge } \\
\text { assumptions, to see the world in new ways, and to question existing } \\
\text { stereotypes or generalizations. The leader's ideas may be different from } \\
\text { followers' existing beliefs but a visionary leader can persuade followers } \\
\text { of his or her ideas because of the high trust and commitment that } \\
\text { followers of visionary leaders demonstrate. }\end{array}$ \\
\hline $\begin{array}{l}\text { Developing the } \\
\text { organization }\end{array}$ & $\begin{array}{l}\text { Visionary leaders are said to create organizational conditions that allow } \\
\text { followers to pursue the vision. They structure the organization so that } \\
\text { followers can function efficiently and without unnecessary bureaucracy. } \\
\text { They select, train, and acculturate followers who are willing and able to } \\
\text { work toward the vision. They also develop reward and punishment } \\
\text { systems to motivate followers toward vision pursuit. }\end{array}$ \\
\hline
\end{tabular}

(Kirkpatrick, 2004, p.1617)

Some of the characteristics of visionary leadership such as empowerment, supporting behavior, and intellectual stimulation are correlated positively with organizational commitment of subordinates (Yukl, 2002). Therefore, it can be presumed that visionary leadership behavior will create trusted leader member relationship and higher commitment of employees.

\section{Organizational Commitment (OC)}

Organizational commitment indicates the emotional attachment of an employee's and the identification of and involvement in their organizations (Mayer \& Allen, 1991). It is a psychological state that relates to the employees' beliefs in their organization's goals, the shared sense of the importance of its values, and the feeling of personal satisfaction derived from their involvement in organizational activities (Mayer \& Allen, 1991). Although early researchers considered $\mathrm{OC}$ as one-dimensional construct later researches claimed that it is a multidimensional construct. Mayer \& Allen,
(1991) themselves conceptualized OC having three dimensions known as affective, normative and continuous commitment. Mowday, et al. (1979) defined OC as (1) a strong beliefs in and acceptance of organizational goals and values, (2) a willingness to exert considerable efforts on behalf of the organization and (3) a strong desire to remain as a member of the organization. Researchers over the past years have found that OC is positively associated with participation, power, teamwork and professionalism (Welsch \& Lan Van, 1981).

One of the determinant of OC of employee is the leadership behavior of his immediate superior. Among the various leadership behavior, visionary leadership has been found to associate positively with OC of employees (DuBrin, 1998).

\section{Leader Member Exchange (LMX)}

Leader member exchange predicts the type of relationship a particular leader keeps with his/her subordinates. LMX 
theory describes the process through which leader determines roles and expectations relating to his subordinates (Dansereau, Graen, \& Haga, 1975). Further, leader may keep different relationship with different subordinates. Leader Member Exchange theory (LMX) explains this differentiated and personalized relationship between the leader and members of the group. The LMX theory argues that leaders will keep different relationship with different subordintates. It identfies two type of relationships: low -quality LMX relationship and high-quality LMX relationship. In low-quality LMX, leader tends to maintain just a contractual relationship with members while in highquality LMX, the leader goes beyond the contractual relationship and develops a psychological contractual relationship (Graen \& Uhl-Bien, 1995). The quality of the mutual relationship is a function of the trust, respect, and mutual obligations that exist within the relationship. On the other hand, the level of outcomes of the LMX relation will be determined by the quality of that relationship. The possible outcomes of the LMX relationship are said to be variables such as performance, turnover, job satisfaction, organizational commitment, innovation and organizational citizenship behavior at dyads (Graen \& Uhl-Bien, 1995).

The nature of the leader member exchange affect to the leadership effectiveness. The nature of LMX has been conceptualized as either high quality and low quality based on the type of exchange the leader and subordinates engage (Liden, Sparrowe, \& Wayne, 1997). High quality LMX is based on economic exchange while high quality LMX is based on social exchange between leaders and subordinates. High quality social exchange occurs when leaders are honest, trustworthy, and genuinely concerned about well-being of their subordinates while low quality economic exchange tends to be promoted when leader provides only economic advantages for subordinates for performance (Erdogan, Liden, \& Kraimer, 2006; Wayne, Shore, Boomer, \& Tetrick, 2002). Researchers have found a possible effect of LMX on leadership effectiveness depending of the nature of LMX. High quality LMX improves the resulting of employees outcomes such as performance, commitment and satisfaction (Gerstner \& Day, 1997) which are also the leadership related employees outcomes. Leadership that promotes high quality LMX is found to be promoting employees' motivation in achieving challenging tasks and their trust and confidence for such kind of task accomplishment (Dirks \& Ferrin, 2002). On the other hand, Yukl and Fu (2009) claim that leader with high quality LMX consult more with their subordinates about important decisions and use their ideas and suggestions for decision making.

\section{Mediating Role of LMX}

The leader-member relationship is not straightforward. The influencing pattern is affected by many factors associated with both the leader and members (Bauer \& Green, 1996). These factors interacting with LMX relationship may either reinforce or attenuate the influence flaws between the leader and his subordinates (Golden \& Veiga, 2008). These interacting variables can be identified as mediating on the LMX relationship. Hogg, Martin, Epitropaki, Mankad, Svensson and Weeden (2005) claimed that these factors interacting with LMX predict the outcomes of the LMX relationship. Researchers have identified mediating variables on LMX relations such as self-efficacy and organizational identification (Walumbwa, Mayer, Weng, Wang, Workman, \& Chistensen, 2011), organizational support, (Sluss, Kilmchak, \& Holmes, 2008), etc. These variables mediate the LMX relationship in that 
they influence the flaw of LMX to either enhance or decline. For instance, high self-efficacy of subordinates will improve the positive effect of leadership on employee outcomes in LMX relationships (Walumbwa et al., 2011). However, it is absevable that researchers have paid their attention more on interactive variables rather than LMX as a aggregate variables. Therefore, the present study was intended to assess the mediating effect of LMX as a aggregate variable on visionay leadership and OC relation.

\section{Methods}

\subsection{Sample}

The sample of this study were 200 graduates' students who were enrolled for postgraduate courses of Faculties of Commerce and Management Studies in Sri Lanka. The participants represents both the private and public sector organizations. 132 respondents are male and 68 were female. Almost half of them were between 25 to 35 years old, and most of them have served in their respective organizations under the supervision of single manager for more than five years. $67 \%$ of the respondent represents middle level management, while $10 \%$ are of top level managers. Most of them are graduate and some of the respondents have followed professional courses in their respective field.

\subsection{Data Collection Procedure}

Data was collected by administering the questionnaire personally among the sample respondents. Respondents were given two week time to fill the questionnaire and returned them. However, a reminder was made after one week so as to ensure the expected response rate. After two weeks' time, 142 respondents have returned the filled questionnaires which is $71 \%$ response rate. This high rate of response was achieved given that sample is consisted of postgraduate students who have a higher enthusiasm in researching. However, 12 questionnaires were found to be incomplete and they were excluded from the analysis.

\subsection{Measures}

The quality of LMX was assessed with LMX-7 developed by (Scandura \& Graen, 1984). This seven item instrument is scaled on five point anchored response choices with unique anchored for each item. A Sample item is "How willing are you to do extra work to help your boss with a difficult problems". This measurement instrument was claimed to be the most validated method for assessing the LMX (Hassan, Mahsud, Yulk, \& Prussia, 2012).

Organizational commitment questionnaire (OCQ) developed by Mowday, et al. (1979) was sued to measure the degree OC of respondents. Scores of the items scaled on five Likert's scale were summed indicating that higher score represent high degree of OC while law score means low level of OC.

Visionary leadership was measured by using the adapted measure of Conger \& Kanungo, (1987). This instrument assesses the vision and articulation, sensitivity to member's needs, environmental sensitivity, and flexibility to change dimensions of visionary leadership.

\subsection{Data Analysis Procedure}

Data of the study was analyzed using structural equation modeling (SEM) since it provides a comprehensive analysis for detecting mediating effect of variables. As a first step, Confirmatory Factor Analysis (CFA) was used for testing the 
validity and reliability of the measures by testing the measurement models as prescribed by Byrne, (2010). Then, a model for testing the mediating effect of LMX was developed and tested against the collected data.

\section{Results}

As the first step in data analysis, confirmatory factor analysis (CFA) was conducted for all measurement model based on the recommended model fit indices of Kline (2005). The items of the measures recorded statistically significant factor loadings for each items $(\mathrm{p}<0.10)$ except for one item of the measurement of visionary leadership and two items of LMX. Anyway, for further verification of the construct and discriminant validity of the measure, model fix indices were considered. For better model fit, Kline (2005) claimed that chi square ratio $(\chi 2 / \mathrm{df})$ should be less than 3.00 , values for comparative fit index (CFI) and incremental fit index (IFI) should be below .10, and root mean square error of approximation (RMSEA) should be less than .07. The measurement models of this study recorded the prescribed level indicating a better model fit. The chi square ratio $\left(\chi^{2} / \mathrm{df}\right)$ recorded a value of .202, .221 and CFI and IFI recorded .94 and 0.92 for visionary leadership and OC respectively. The RMSEA value is 0.06 for visionary leadership and is .070 for $\mathrm{OC}$ which is the indication that the error term in the measurement models are at minimum. In case of LMX, the value recorded for chi square ratio $(\chi 2 / \mathrm{df}), \mathrm{CFI}$, IFI and RMSEA are 0.201, .92,0,91 and 0.065 respectively.

As a further verification, the measurement model was tested to examine whether they hold as unidimensional or multi-dimensional measurement model. It proved that measurement models stand as multidimensional as claimed by the previous studies (Scandura \& Graen, 1984; Mowday, Richard, \& Lyman, 1979). The model fit indices recorded a better result for multi-dimensional model $(\chi 2=656.78$, (9), $\quad \mathrm{p}<.010), \quad \mathrm{CFI}=.94, \quad \mathrm{IFI}=0.95$, RMSEA $=0.06)$ than uni-dimensional model $(\chi 2=456.78,(3), \mathrm{p}<.050), \mathrm{CFI}=.84$, $\mathrm{IFI}=0.85, \mathrm{RMSEA}=0.08)$.

\section{Testing of Hypothesis}

The full moderating model was tested using the structural equation modeling with AMOS 16, so that the estimated standard values can be used for hypotheses testing. The model fit indices of the full model recorded the threshold values $\left(\chi 2=156.78,(33), \chi^{2} / \mathrm{df}=0.23\right.$, $\mathrm{p}<.010), \quad \mathrm{CFI}=.94, \quad \mathrm{IFI}=0.91$, RMSEA=0.07) which indicates the appropriateness of using estimated values for hypotheses testing. On the other hand, the model without the mediating effect of LMX did not indicated better results than the model with mediating model with LMX impact. The model fit improvement of the mediating model over direct model $(\Delta \chi 2=56.78, \quad(3), \quad \mathrm{p}<.010), \quad \mathrm{CFI}=.94$, IFI=0.91, RMSEA=0.07) reveals a possible mediating effect of LMX between visionary leadership and OC.

The following figure depicts the tested mediating model along with estimated standard parameters.

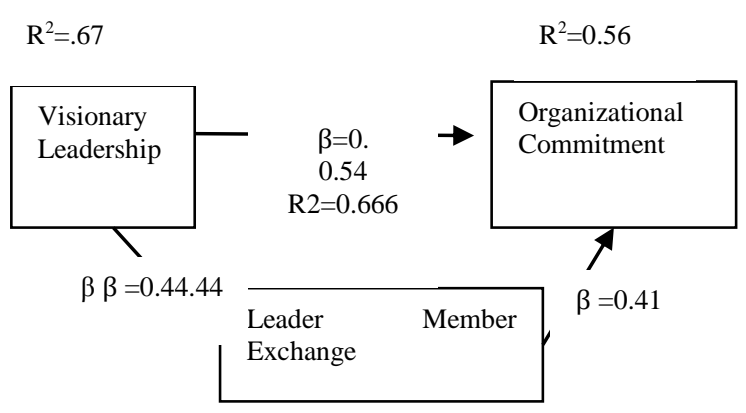


As shown in the figure, visionary leadership had a significant positive relationship with employees' OC $(\beta=0.54, \quad p<0.01)$. Further, visionary leadership recorded a positive association with leader member exchange $(\beta=0.44, p<0.01)$ and LMX had a positive relationship with $\mathrm{OC}$ of Employees $(\beta=0.41, p<0.01)$. Though this indicated a possible mediating effect of LMX as claimed by Kenny \& Judd, (1984) the estimated standard value for indirect effect was considered. The indirect relationship between visionary leadership and $\mathrm{OC}$ via LMX was statistically significant $(\beta=0.34, p<0.01)$. it further revealed that the direct and indirect relationships together explains $67 \%$ of variance in $\mathrm{OC}$ of employees while the direct effect of visionary leadership accounts for more variance $(51 \%)$ of OC. This reveals that though the LMX increases the degree of OC of employees, visionary leadership alone contributes significantly to enhance the $\mathrm{OC}$ of employees.

\section{The Discussion}

The finding of this study confirms the fact that visionary leadership behavior of leader will improve the $\mathrm{OC}$ of employees as claimed by other researchers. It is the vision that is attractive to subordinates and the way of communication of the leader that promote $\mathrm{OC}$ of employees. Further, visionary leaders foster participation in decision making empower their followers for achieving the vision they set. This way of motivating of subordinates' towards the vision results in commitment towards the vision and organizations (Huang, Yun, Liu, \& Gong, 2010).

Further, it revealed that the quality of LMX will improve the OC of employees with its mediating effect. As the social exchange theory claims (Blau, 1964), high quality relationship of leaders with their subordinates will increase their level of OC. If leaders engage in friendly, warmth and trusted relation with their subordinates', subordinates tends to trust their leaders and that will result in OC of them.

\section{Implication of The Findings}

The findings of the study carry few significant theoretical and managerial implications. On theoretical ground, the findings further confirm the importance of leadership behavior in enhancing the OC of employees. Though the other organizational factor may cause commitment of employees to some extent, leadership behavior particularly the visionary leadership behavior improves the $\mathrm{OC}$ of employees to a lager degree.

On the other hand, this study highlights the fact that the nature of the relationship between the leader and the subordinates is also important. By finding a significant mediating effect of LMX on visionary leadership and OC relationship, it highlights that factors such as LMX will intervene the effect of leadership on OC. As a result, more studies are warranted for further identification of intervening factors on the relationship between visionary leadership and OC.

On practical ground, this study brings significant insights to the practitioners. Setting a inspiring vision and communicating it to the subordinates with participation, trusted and ethical way, not only it improves the commitment of subordinates towards the vision but also the overall commitment to the organization. Therefore, managers should be trained on visionary leadership behaviors so that they can improve both organizational and employees outcomes.

Further, managers should mind their relationship with subordinates. They 
should engage more in a kind of social exchange relation which is mutually beneficial. Mere economic or transactional relationship with subordinates will not improve the OC of subordinates. Leaders should keep warmth, friendly, trusted and ethical relationship with their subordinates which enhance the effect of their leadership on employees' outcomes such as OC.

\section{Conclusion}

This study was carried to examine the mediating effect of leader member exchange (LMX) on the relationship between visionary leadership and OC of employees. It found that there is a positive impact of visionary leadership on OC. Further, it was revealed that LMX has a positive mediating effect on that relationship. This study contributed by bringing out some significant theoretical and practical implications. Anyway, further studies are recommended so that more understanding can be gained on the relationship between leadership and $\mathrm{OC}$ and on intervening mechanism between them

\section{References}

Avolio, J. B., Walumbwa, F. O., \& Weber, T. J. (2009). Leadership;current theories, research, and future direction. Annual Review of Psychology, 60, 421-476.

Bauer, T. N., \& Green, S. G. (1996). Development of leader-member exchange: a longitdinal test. Academy of Management Journal, 39, 1538-1567.

Blau, P. M. (1964). Exchange and power in social life. NewYork: Wiley.
Byrne, B. M. (2010). Structural Equation Modeling (2 ed.). New York: Taylor and Francis.

Colton, D. L. (1985). Vsion. National Forum, 65(2), 33-35.

Conger, J. A., \& Kanungo, R. N. (1987). Towards behavioral theory of charismatic leadership on organizational setting. Academy of Management Review.

Dansereau, F., Graen, G., \& Haga, W. J. (1975). A vertical dyad linkage approach to leadership with formal organizations: a longitudinal investigation of the role making process. Organizational Behavior and Human Performance, 13, 4678 .

Dirks, K. T., \& Ferrin, D. L. (2002). Trust in Leadership: metalanalytical findings and implications for research and practice. Journal of Applied psychology, 87, 611-628.

DuBrin, A. J. (1998).

Leadership:research

findings,practcie, and skills. Boston Toronto: Houghton Mifflin Company.

Erdogan, B., Liden, R. C., \& Kraimer, M. L. (2006). Justice and leadermember exchange: the moderating role of organizational culture. Academy of Management Journal, 49, 395-406.

Gerstner, D. R., \& Day, D. V. (1997). Meta-analytic review of leader memebr exchange theory: correlates and construct issues journal of Applied Psychology, 82, 827-844. 
Golden, T. D., \& Veiga, J. F. (2008). The impact of superior-subordinates relationship on the commitment, job satisfaction, and performance of virtual workers. The Leadership Quaterly, 19, 77-88.

Graen, G. B., \& Uhl-Bien, M. (1995). Development of leader member exchange theory over 25 years:applying multi-level, mulidomain perspective. Leadership Quaterly, 6(2), 219-247.

Hassan, S., Mahsud, R., Yulk, G., \& Prussia, E. G. (2012). Ethicla and empowering leadeship and leader effectiveness. Journal of Management Psychology, 28(2), 134-146.

Hogg, M. A., Martin, R., Epitropaki, O., Mankad, A., Sevensson, A., \& Weeden, K. (2005). Effective leadership in salient groups: revisiting leader-member exchange theory from the perspective of the social identity theory of leadership. Personality and Social Psychological Bulletin, 31, 991-1004.

Huang, X., Yun, J., Liu, J., \& Gong, Y. (2010). Does participative leadership enhance work performance by inducing empowerment and trust? the diiferent effect on managerial and non-managerial subordinates. Journal of Organizational Behavior, 49, 122-143.

Kenny, D. A., \& Judd, C. M. (1984). Estimating the non linear and interactive effect of latent variables. Psychological Bulletin, 96, 201-210.

Kirkpatrick, S. A. (2004). Visionary leadership theory: encyclopidia of leadership . NY: SAGE publication .

Kline, R. (2005). The principles and practices of structural equation modeling . New York: The Guilford Press.

Liden, R. C., Sparrowe, R. T., \& Wayne, S. J. (1997). Leader-memebr exchange theory: the past potential for future. Research in Personnel and Human Resources management, 25, 47-119.

Mayer, J. P., \& Allen, N. J. (1991). A three component conceptualization of organizational commitment. Human Resource Management Review, 108, 61-89.

Mowday, R. T., Richard, S. M., \& Lyman, P. W. (1979). The measurement of organizational commitment. Journal of Vocational Behavior, 14(October), 179-196.

Scandura, T. A., \& Graen, G. B. (1984). Moderating effect of initial leader member exchange status on the effect of a leadership intervention. Journal of Apllied Psychology, 69, 428-436.

Shamir , B., House, R. J., \& Arthur, M. B. (1993). The motivational effect of charismatic leadership: a self concepts based theory. Organizational Science, 4, 577594. 
Sluss, D. M., Klimchak, M., \& Holms, J. J. (2008). Percieved organizational support as a mediator between rational excahnge and organizational identification. Journal of Vocational Behavior, 73, 457-464.

Valenzuela, K. (2007). Leadership Definisions . NY: Prentice Hall.

Waldman, D. A., Ramirez, G. G., House, R. J., \& Puranam, P. (2001). Does leadership matter? CEO leadership attributes and profitability under conditions of percieved environmental uncertainity. Academy of Management Journal, 44, 134-143.

Walumbwa, F. O., Mayer, D. M., Weng, P., Wang, H., Workman, K., \& Chistensen, A. L. (2011). Linking ethical leadership to employee performance: The role of leadermember exchange, self efficacy, organizational identification. Organizational Behavior and Human Decision Process, 115, 204-213.

Wayne, S. J., Shore, L. M., Boomer, W. H., \& Tetrick, L. E. (2002). The role of fair treatment and rewards in perceptions of organizational suprot and leadr-member exchange. Journal of Apllied Psychology, 87, 590-598.

Welsch, H. P., \& Lan Van, H. (1981). Inter-relationship between organizational commitment and job characteristics, job satisfaction, professinal behavior and organizational climate. Human Rellation, 34(12), 1079-1089.

Yulk, G. (2006). Leadership in Organizations (6 ed.). New Jersey: Prentice Hall. 